\title{
Pageantry and power
}

\author{
A cultural history \\ of the early modern \\ Lord Mayor's Show, \\ $15^{8} 5^{-16} 39$

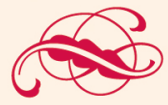

TRACEY HILL

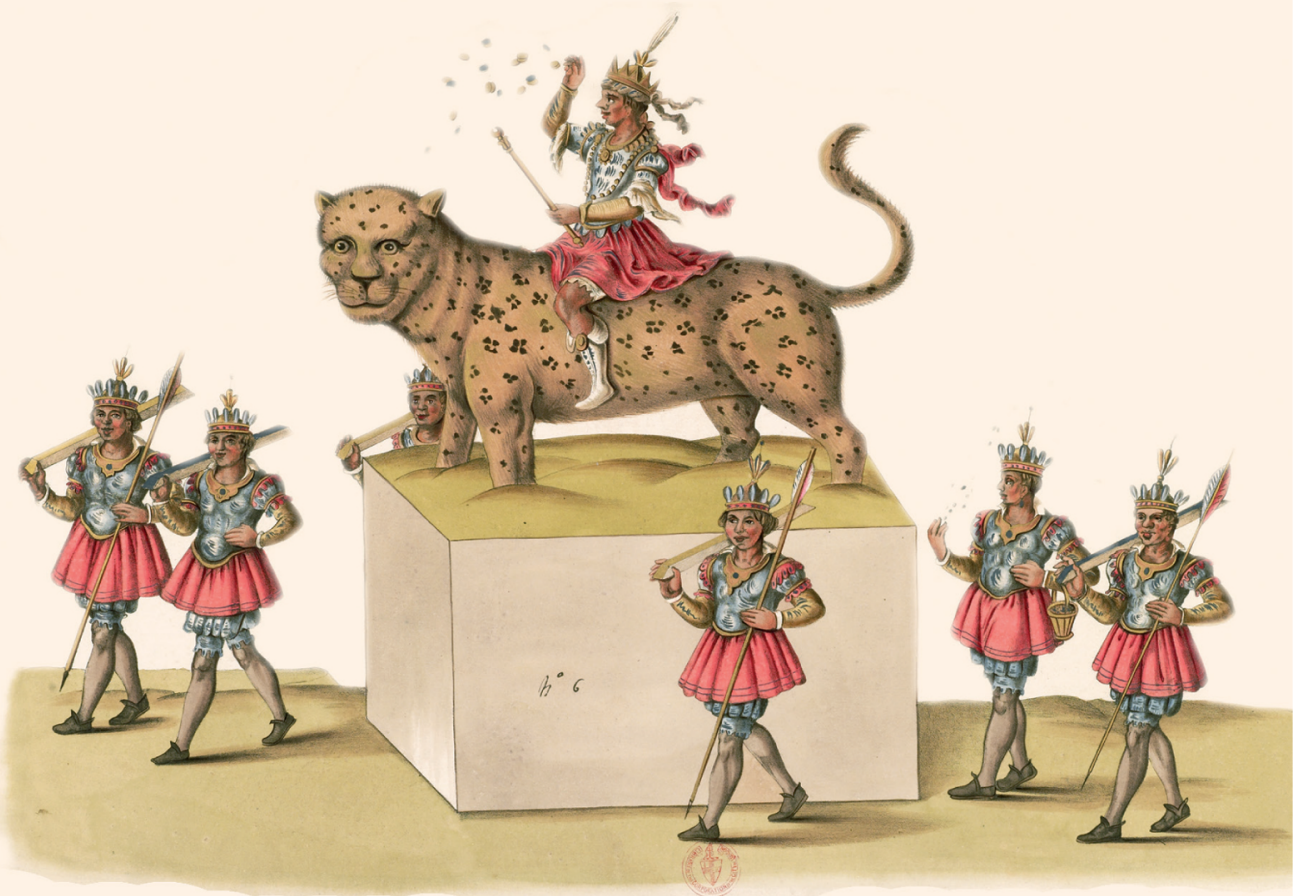




\section{Pageantry and power}

\section{MANCHESTER 1824}

Manchester University Press 
Tracey Hill - 9781526125101

Downloaded from manchesterhive.com at 04/26/2023 03:01:46PM 


\title{
Pageantry and power
}

A cultural history of the early modern Lord

Mayor's Show, 1585-1639

\section{TRACEY HILL}

\author{
Manchester \\ University Press \\ Manchester
}


Copyright (C) Tracey Hill 2010

The right of Tracey Hill to be identified as the author of this work has been asserted by her in accordance with the Copyright, Designs and Patents Act 1988.

Published by Manchester University Press

Altrincham Street, Manchester M1 7JA, UK

www.manchesteruniversitypress.co.uk

British Library Cataloguing-in-Publication Data is available

Library of Congress Cataloging-in-Publication Data is available

ISBN 9780719090127 paperback

First published by Manchester University Press in hardback 2010

The publisher has no responsibility for the persistence or accuracy of URLs for any external or third-party internet websites referred to in this book, and does not guarantee that any content on such websites is, or will remain, accurate or appropriate. 